\title{
SOSIO KULTUR PEMULUNG DAN PERANNYA DALAM KESEIMBANGAN LINGKUNGAN SEKITAR DENGAN MENGKATEGORISASIKAN BARANG BEKAS
}

\author{
Suhartono \\ Universitas Terbuka \\ Email: hart@ut.ac.id
}

Naskah diterima : 9 Maret 2015, direvisi : 17 April 2015, disetujui : 30 April 2015

\begin{abstract}
This study aims to describe the socio-cultural, factors that make up the work ethic, and workflow scavengers in categorizing the thrift as a source of information and support materials for learning. The method used in the study is a survey with a qualitative approach that is supported by quantitative data. Primary data was collected by questionnaire and in-depth interviews, secondary data obtained from documents and documentation Pamulang 2. When the study area from August to November 2012 and continued in the months from January to March 2013. The results showed that almost all scavengers assess both economically job as scavengers can be used as a primary source of income. Skill and dexterity in scavenging into a large capital gain product mulung more. The process contributes to the way categorization of junk into parts easily understood and utilized by stakeholder. Expected investment process at thrift concept has dimensions of knowledge that can be used as a unique learning model for the community. Categorization of secondhand goods can provide economic value to the scavengers also become media education and media knowledge recycling process to balance the surrounding environment.
\end{abstract}

Keywords: socio-cultural; scavengers; the dimensions of the role; the categorization of thrift

\begin{abstract}
Abstrak
Penelitian ini bertujuan untuk mengetahui gambaran sosio-kultur, faktor yang membentuk etos kerja, dan alur kerja pemulung dalam mengkategorisasikan barang bekas sebagai sumber informasi dan bahan pendukung untuk pembelajaran. Metode yang digunakan dalam penelitian adalah survei dengan pendekatan kualitatif yang didukung data-data kuantitatif. Data primer dikumpulkan dengan kuesioner dan wawancara mendalam, sedangkan data sekunder diperoleh dari dokumen dan dokumentasi wilayah Pamulang 2. Hasil penelitian menunjukkan bahwa hampir seluruh pemulung menilai baik pekerjaannya karena secara ekonomi menjadi pemulung dapat dijadikan sumber penghasilan utama. Keterampilan dan kecekatan dalam memulung menjadi modal besar mendapatkan produk mulung yang lebih banyak. Proses penanaman konsep pada barang bekas diharapkan memiliki dimensi pengetahuan yang dapat dijadikan model pembelajaran yang unik bagi masyarakat. Pengkategorisasian barang bekas selain dapat memberikan nilai ekonomis bagi para pemulung juga menjadi media edukasi dan media pengetahuan proses daur ulang untuk keseimbangan lingkungan sekitar.
\end{abstract}

Kata kunci: sosio-kultur; pemulung; dimensi peran; kategorisasi barang bekas

Pengutipan: Suhartono. (2015). Sosio Kultur Pemulung dan Perannya dalam Keseimbangan Lingkungan Sekitar dengan Mengkategorisasikan Barang Bekas. SOSIO DIDAKTIKA: Social Science Education Journal, 2(1), 2015, 38-49. doi:10.15408/sd.v2i1.1350

Permalink/DOI: http://dx.doi.org/10.15408/sd.v2i1.1350 


\section{A. Pendahuluan}

Salah satu masalah lingkungan yang hingga kini masih menjadi masalah besar adalah pengelolaan sampah industri dan rumah tangga. Rata-rata setiap pabrik di Jabotabek menghasilkan satu ton limbah plastik setiap minggunya. Jumlah tersebut akan terus bertambah, disebabkan sifat-sifat yang dimiliki plastik, antara lain tidak dapat membusuk, tidak terurai secara alami, tidak dapat menyerap air, maupun tidak dapat berkarat, dan pada akhirnya menjadi masalah bagi lingkungan. ${ }^{1}$ Sedangkan komposisi limbah plastik yang dibuang oleh setiap rumah tangga adalah $9,3 \%$ dari total sampah rumah tangga. ${ }^{2}$

Barang-barang bekas yang terbuang di tempat sampah menjadi potret rutin yang sering kita jumpai di setiap sudut pemukiman. Hubungan antara keberadaan barang bekas dengan lingkungan tidak terlepas dari kegiatan para pemulung yang dapat dijadikan agen pengelola limbah barang bekas baik untuk bahan daur ulang atau dimanfaatkan sebagai sesuatu yang masih berguna. Para pemulung sebagai aktor dalam kegiatan pengelolaan barang bekas dari sampah rumah tangga menjadi fenomena sosial yang penting untuk masalah pengelolaan lingkungan. Kehadiran pemulung telah membantu dalam pembangunan meskipun tampaknya kecil yaitu secara tidak sengaja telah turut andil dalam menjaga kebersihan lingkungan.

Hubungan antara keberadaan pemulung dengan kondisi barang bekas menjadi fokus dalam penelitian ini. Dimensi keterkaitan tersebut memiliki dampak yang dapat dijadikan upaya pemanfaatan barang bekas sebagai media pembelajaran di sekolah. Peran pemulung dalam mengkategorisasikan barang bekas dapat dijadikan sumber informasi dan penyedia barang bekas untuk media pembelajaran.

Adapun penelitian ini bertujuan untuk:

1. Mengetahui gambaran tentang sosio-kultur pemulung.

2. Mengetahui faktor yang membentuk etos

\footnotetext{
G. L. Young, "Passamaquoddy Technology Recovery Scrubber $\begin{array}{ccc}1 & \text { G. L. Young, "Passamaquoddy Technology Recovery Scrubber } \\ \text { Process Update"; Specialty Conference on Waste Combustion in Boilers and Industrial }\end{array}$ - Process Update"; Specialty Conference on Waste Combustion in Boilers and
Furnaces, Air \& Waste Management Association, (Kansas City. 1994), h. 5.

2 D. Hartono, Alternatif Pemenuhan Kebutuhan Air Bersib oleh PDAM Kota Semarang, Tesis Program Pascasajana, Magister Teknik Pembangunan Wilayah dan Kota, Universitas Diponegoro, 2005 (tidak dipublikasikan).
}

kerja pemulung.

3. Mengetahui cara pandang pemulung dalam mengkategorisasikan barang bekas sebagai sumber informasi dan bahan pendukung media pembelajaran di sekolah yang murah dan ramah lingkungan.

4. Mengetahui alur kerja pemulung dalam mengkategorisasikan barang bekas sebagai sumber informasi dan bahan pendukung untuk media pembelajaran.

Penelitian ini diharapkan dapat bermanfaat secara teoritis maupun praktis. Secara teoritis, diharapkan dapat menghasilkan kajian konsep hubungan antara manusia dan lingkungan sebagai suatu sistem dengan paradigma sosio kultur dari para pemulung di dalamnya, sehingga dapat memperkaya teori mengenai etos kerja dan masalah ke-pemulung-an yang telah ada. Secara praktis, hasil penelitian diharapkan dapat bermanfaat sebagai masukan bagi:

1. Pemda setempat dan masyarakat luas dalam pemanfaatan barang bekas.

2. Para pemulung dan pekerja lain yang terkait dalam pemanfaatan barang bekas.

3. Guru dan siswa dalam memanfaatkan media pembelajaran dengan menggunakan bahan pendukung dari barang bekas.

4. Peneliti lain yang tertarik untuk menambah wawasan dan pengetahuannya dalam memahami hubungan manusia dengan lingkungan.

Hubungan antara individu dan lingkungan dapat dikategorikan ke dalam 4 jenis, yaitu: (1) individu dapat bertentangan dengan lingkungannya; (2) individu dapat menggunakan lingkungannya; (3) individu dapat berpartisipasi (ikut serta) dengan lingkungannya; dan (4) individu dapat menyesuaikan diri dengan lingkungannya.

Lingkungan sosial tidak hanya berlangsung searah dalam arti bahwa hanya lingkungan saja yang mempunyai pengaruh terhadap individu, tetapi antara individu dengan lingkungan terdapat hubungan yang saling timbal balik, yaitu lingkungan berpengaruh pada individu, dan sebaliknya individu juga mempunyai pengaruh pada lingkungan. ${ }^{4}$

Gerungan, Psikologi Sosial, (Jakarta: Pratama, 2009), h. 7. B. Walgito, Psikologi Sosial, (Yogyakarta: Andi Offset, 1994), h.22. 
Dalam mencermati bagaimana hubungan antara manusia dan lingkungan, nampaknya perlu dikembangkan suatu konsep rekayasa lingkungan yang basisnya adalah kesadaran manusia akan lingkungan dam pembentukan perilaku manusia yang ramah lingkungan.

Secara umum lingkungan dapat dibedakan menjadi dua jenis, yaitu: (1) lingkungan fisik; dan (2) lingkungan non-fisik (sosial). Lingkungan fisik adalah lingkungan yang berupa alam, di mana lingkungan alam yang berbeda akan memberikan pengaruh yang berbeda pula kepada individu manusia. Sedangkan lingkungan sosial adalah lingkungan masyarakat dalam suatu komunitas tertentu di mana di antara individu dalam masyarakat tersebut terjadi interaksi. Lingkungan sosial akan memberikan pengaruh yang cukup besar terhadap perilaku manusia. ${ }^{5}$

Lingkungan sosial dapat dibedakan menjadi: (a) lingkungan sosial primer, dan (b) lingkungan sosial sekunder. Pengaruh lingkungan sosial primer ini akan lebih mendalam bila dibandingkan dengan pengaruh lingkungan sosial sekunder karena dalam lingkungan sosial sekunder, individu satu kurang mengenal dengan individu yang lain. Namun demikian pengaruh lingkungan sosial, baik lingkungan sosial primer maupun lingkungan sosial sekunder sangat besar terhadap keadaan individu sebagai anggota masyarakat. ${ }^{6}$

Sejalan dengan konsep di atas, apabila seseorang membicarakan lingkungan hidup, maka biasanya yang dipikirkan adalah hal-hal atau apa-apa yang berada di sekitar manusia, baik sebagai individu maupun dalam pergaulan hidup. Lingkungan hidup tersebut biasanya dibedakan dalam kategori-kategori, sebagai berikut?:

1. lingkungan fisik, yakni semua benda mati yang ada di sekeliling manusia;

2. lingkungan biologis, yaitu segala sesuatu di sekeliling manusia yang berupa organisme yang hidup, di samping manusi itu sendiri; dan

3. lingkungan sosial, yang terdiri dari orangorang secara individual maupun kelompok

\footnotetext{
5 Oman Sukmana, Dasar-Dasar Psikologi Lingkungan, (Malang: Bayu Media, 2003), h.12.

6 Walgito, Ibid,. h. 20.

J. Subagyo, Hukum Lingkungan, Masalah Dan Penanggulangannya,

(Jakarta: Rineka Cipta, 2003) h. 16.
}

yang berada di sekitar manusia.

Berkaitan dengan konsepsi tentang lingkungan sosial, bahwa manusia memerlukan lingkungan sosial yang serasi demi kelangsungan hidupnya. Untuk mewujudkan lingkungan sosial yang serasi diperlukan lagi kerjasama kolektif di antara sesama anggota. Kerjasama itu dimaksudkan untuk membuat dan melaksanakan aturan-aturan yang disepakati bersama oleh warga sebagai mekanisme pengendalian perilaku sosial. Aturan-aturan itu, seringkali terwujud dalam bentuk pranata atau norma-norma sosial yang harus dipatuhi oleh setiap anggota kelompok (norma hukum). ${ }^{8}$

Orang miskin dipandang sebagai satuan sosial yang tegas batas-batasnya, yang menyandang suatu kebudayaan kemiskinan yang khas, yang berbeda dari masyarakat lain di luarnya. ${ }^{9}$ Kemiskinan dan kehidupan pemulung di Indonesia seperti dua sisi mata uang yang tidak dapat dipisahkan. Kehidupan pemulung sebagai komunitas marjinal sangat berdekatan dengan kondisi yang sangat memprihatinkan. Setiap hari mereka bergelut dengan urusan sampah yang kotor dan kuman yang sering kali masyarakat luas tidak menginginkan kondisi tersebut berada di kehidupannya. Biasanya para pemulung hidup dari limbah sampah, bahkan mereka dapat tinggal dan menjalani aktivitas sehari-hari dengan limbah sampah. Para pemulung bekerja mengumpulkan barang-barang bekas dengan cara mengerumuni muatan truk sampah yang tengah di bongkar. Barang bekas yang telah berkumpul kemudian dipisah-pisah menurut jenisnya, sebelum akhirnya dijual kepada pedagang barang bekas atau lapak. Pemahaman tentang lapak atau penampung adalah orang yang mempunyai modal atau dukungan modal untuk membeli beberapa jenis, atau satu jenis barang bekas dari pemulung. Jasa lapak selain sebagai pembeli tetap adalah ia menanggung sarana transportasi untuk mengambil barang bekas dari pemukiman liar, sehingga para pemulung yang menjadi anak buahnya tidak perlu menanggung ongkos angkutan. Kegiatan pemulung tersebut menggunakan alat bantu yang berupa gerobak dan karung.

\footnotetext{
8 J. Purba, Pengelolaan Lingkeungan Sosial, (Jakarta: Yayasan Obor Indonesia, 2002), h. 27.

9 S. Fedyani, Catatan Refleksi Antropologi Sosial Budaya, (Jakarta: Institut Antropologi Indonesia (IAI), 2011), h. 5.
} 


\section{B. Metode Penelitian}

Tahap penelitian dibagi dua, yakni tahap pemahaman lokasi dan masalah, kemudian dilanjutkan tahap pendalaman. Tahap pemahaman lokasi dan masalah merupakan pengenalan area dan masyarakat yang diteliti. Dalam tahapan ini dilakukan proses identifikasi lingkungan fisik dan lingkungan sosial. Beberapa alat bantu seperti jalur aktivitas pemulung, pencatatan mobilitas, pembagian area mulung (mangkal), jaringan sosial, penyusunan kelompok-kelompok kerja pemulung, kegiatan di lapak, dan lain-lain. Setelah memahami kondisi sosio kultur pemulung dan aktivitas mulung, maka dilakukan tahap pendalaman terhadap topik-topik yang menjadi perhatian dari penelitian ini.

Penelitianinidilakukan disekitarpemukiman warga Pamulang 2 yang merupakan bagian dari Kelurahan Pondok Benda Kecamatan Pamulang Kota Tangerang Selatan Provinsi Banten. Penelitian lapang (fieldwork) dilakukan mulai Agustus 2012 sampai dengan November 2012 dilanjutkan bulan Januari-Maret 2013. Penelitian ini telah melibatkan para pemulung baik secara kelompok maupun individu.

Adapun pendekatan yang digunakan dalam penelitian ini adalah dengan ethnoscience, yaitu memahami perspektif lokal dengan menerapkan interview etnografi untuk memperoleh sejumlah taksonomi pengetahuan lokal, khususnya tentang strategi adaptasi dalam memulung, sistem kategorisasi barang bekas dan pengetahuan bahan pendukung barang bekas sebagai barang yang dapat digunakan kembali untuk keperluan tertentu. Jumlah informan tidak dibatasi, sebanyak mungkin dengan memprioritaskan sejumlah key informans.

Pada saat observasi awal di lingkungan pemukiman banyak dijumpai beberapa kelompok pemulung yang rutin mengunjungi tempat sampah rumah warga. Para pemulung terlihat terorganisir dan ditentukan dengan ritme waktu yang bergantian untuk memulung barang bekas sebagai limbah sampah warga. Wilayah pemukiman yang dimaksud adalah perumaham Pamulang 2 yang terdiri dari 15 gang/jalan sekunder dengan bagian Barat dan Timur pada setiap ruas jalan. Di tengah-tengah perumahan terdapat jalan utama yang dinamakan jalan raya Pamulang 2. Alasan pemilihan tempat penelitian ini dikarenakan karakteristik pemukiman yang sangat beragam berdasarkan status sosial warga, jenis pekerjaan, gaya hidup dan kondisi wilayah yang sangat terbuka (tanpa adanya penjagaan keamanan yang tertutup) sehingga setiap warga bebas melakukan mobilitas. Di sekitar pinggiran kompleks perumahan terdapat lapak tempat pemulung mengumpulkan hasil mulungnya yang menyatu dengan tempat tinggal pemulung.

Metode etnosain yang telah digunakan dalam penelitian ini diambil dari disiplin antropologi, yaitu menyusun sejumlah taksonomi pengetahuan yang ada pada pemulung dan kelompok pemulung lain. Caranya adalah dengan menerapkan interview etnografi untuk memperoleh pemahaman emic pemulung dan kelompok pemulung lain (perspektif lokal) tentang lingkungan sekitar mereka, khususnya pencarian barang bekas sebagai limbah sampah. Asumsi yang digunakan adalah lingkungan fisik yang dapat dilihat sehari-hari dan memahami perbedaan antara satu orang dengan orang lainnya (perceived environment). Pemahaman yang berbeda tersebut dapat menuntun seseorang untuk bersikap dan berperilaku yang berbeda dari orang lain dalam mengkategorisasikan barang bekas sebagai limbah sampah.

Pemahaman berupa pengetahuan seseorang tentang barang bekas sebagai limbah sampah menjadi obyek dalam menerapkan metode ini. Pengetahuan-pengetahuan lokal yang apabila sudah diperoleh disusun dalam bentuk taksonomi-taksonomi (pola ideal). Walaupun pengetahuan tersebut bukan merupakan satusatunya motivasi seseorang untuk mengerjakan kategorisasi barang bekas sebagai limbah sampah tertentu, namun dengan memahami pengetahuan lokal dari para pemulung tersebut telah membantu memahami bagaimana seandainya peneliti berada di komunitas tersebut dengan berperilaku yang "tepat".

Triangulasi yang digunakan dalam penelitian ini adalah triangulasi metode, yakni membandingkan temuan penelitian yang diperoleh dari beberapa teknik pengumpulan data. Temuan penelitian yang dibandingkan meliputi (a) temuan hasil pengamatan dengan hasil wawancara, (b) temuan hasil pengamatan 
dengan dokumentasi kegiatan, dan (c) temuan hasil wawancara dengan dokumentasi kegiatan. Dalam penelitian ini, analisis data yang telah dilakukan mencakup tiga tahap, yaitu: (1) reduksi data, (2) penyajian data, dan (3) penarikan kesimpulan dan verifikasi data.

Tahap penarikan kesimpulan dan verifikasi data yang telah dilakukan yaitu menarik kesimpulan hasil penelitian yang diambil dari hasil reduksi dan panyajian data yang merupakan kesimpulan sementara. Kesimpulan sementara ini masih dapat berubah jika ditemukan buktibukti kuat lain pada saat proses verifikasi data di lapangan. Selanjutnya kesimpulan hasil penelitian dijabarkan sesuai dengan temuan dan hasil analisis data secara utuh.

\section{Pembahasan}

Secara komprehensif, bagian ini menguraikan keberadaan pemulung di wilayah Pamulang, khususnya seputar pemukiman Perumahan Pamulang 2. Penjelasan akan dimulai dari profil pemulung secara umum, keadaan wilayah di mana pemulung tinggal, jumlah pemulung, jumlah lapak atau kelompok kelompok tinggal dan menjual hasil pulungan di wilayah pamulang, sumber pendanaan pemulung. Secara khusus dijelaskan kondisi fisik, demografi, dan kondisi eksistensi pemulung yang ditinjau dari aspek ekonomi, sosial kelembagaan, psikologi, dan teknologi dengan perkembangan teknologi mengkategorisasikan barang bekas.

Pemulung di wilayah Pamulang 2 terdiri dari orang tua, anak muda, pria dan wanita bahkan belakangan ini ada juga anak-anak yang bekerja sebagai pemulung karena faktor ekonomi orang tua yang tidak mencukupi yang memaksa anak untuk ikut bekerja dalam memenuhi kebutuhan hidup sehari-hari. Berikut ditampilkan tabel karakteristik pemulung di wilayah Pamulang 2, lihat Tabel 1.

Selanjutnya dapat ditampilkan data komposisi pekerjaan pemulung berdasarkan kelompok umur di wilayah Pamulang 2, lihat Tabel 2.

Penghitungan data komposisi jumlah pemulung tidak begitu akurat. Hal ini berdasarkan hitungan dari sumber antar teman sejawat pemulung. Ketidakakuratan disebabkan setiap hari jumlah pemulung terkadang bertambah dan berkurang. Jumlah pemulung berdasarkan lokasi lapak yang ada di wilayah Pamulang 2 berjumlah 12 lapak. Setiap lapak terdapat 8-12 pemulung.

Penghitungan data komposisi jumlah pemulung tidak begitu akurat. Hal ini berdasarkan hitungan dari sumber antar teman sejawat pemulung. Ketidakakuratan disebabkan setiap hari jumlah pemulung terkadang bertambah dan berkurang. Jumlah pemulung berdasarkan lokasi lapak yang ada di wilayah Pamulang 2 berjumlah 12 lapak. Setiap lapak terdapat 8-12 pemulung.

Tabel 1. Karakteristik Pemulung di Wilayah Pamulang 2

\begin{tabular}{|c|c|c|}
\hline No & Karakteristik & Uraian \\
\hline 1. & Jenis kelamin & laki-laki $(85 \%)$ dan perempuan $(15 \%)$ \\
\hline 2. & Usia pemulung & $\begin{array}{l}\text { Usia dewasa }(61,9 \%) \text { anak-anak }(9,5 \%) \\
\text { dan remaja }(28,6 \%)\end{array}$ \\
\hline 3. & $\begin{array}{l}\text { Status } \\
\text { perkawinan }\end{array}$ & $\begin{array}{l}\text { status menikah/berumah tangga }(70 \%) \\
\text { dan sisanya }(30 \%) \text { pemulung masih } \\
\text { sendiri/lajang dan berstatus janda/duda }\end{array}$ \\
\hline 4. & Etnis & $\begin{array}{l}(70 \%) \text { Cirebon-Indramayu-Kuningan } \\
\text { (Pantura), }(30 \%) \text { etnis Jawa dan Sunda } \\
\text { tidak tamat SD }(65 \%),(15 \%) \text { tamat SD, }\end{array}$ \\
\hline 5. & Pendidikan & SMP $(5 \%)$ dan sisanya tidak pernah \\
\hline 6. & Tempat tinggal & $\begin{array}{l}\text { sekolah } \\
\text { Sebagian besar pemulung tinggal di } \\
\text { rumah kontrakan/lapak/Bos ( } 82 \%) \text {. } \\
\text { Mereka tinggal berkelompok-kelompok } \\
\text { dan bersama dalam satu rumah dengan } \\
\text { pemulung lain. Biasanya mereka } \\
\text { menyewa tempat yang memiliki halaman } \\
\text { luas untuk menampung hasil mulungnya. }\end{array}$ \\
\hline 7. & Sanitasi & $\begin{array}{l}\text { Bagi pemulung yang tinggal di rumah } \\
\text { kontrakan bersama-sama mengunakan } \\
\text { fasilitas yang tersedia, seperti MCK, } \\
\text { sumber air di kali/sungai secara } \\
\text { bergantian }\end{array}$ \\
\hline 8. & $\begin{array}{l}\text { Kebiasaan pola } \\
\text { hidup }\end{array}$ & $\begin{array}{l}\text { Pemulung memasak sendiri makanannya } \\
\text { dan terkadang membeli dari warung. } \\
\text { Selain itu, dalam kesehariannya } \\
\text { mengkonsumsi makanan di tempat- } \\
\text { tempat jalanan dan makan di tempat } \\
\text { mangkal. Dalam usahanya membersihkan } \\
\text { diri, pemulung rata-rata mandi hanya } \\
\text { satu kali sehari. Mereka sebagian besar } \\
\text { tidur beralaskan plastik/terpal bersamaan } \\
\text { dengan hasil mulungnya. Rumah petakan } \\
\text { yang dikontrak biasanya digunakan untuk } \\
\text { tinggal anak-anak dan istri dari Bos-nya }\end{array}$ \\
\hline 9. & $\begin{array}{l}\text { Keluhan } \\
\text { penyakit }\end{array}$ & $\begin{array}{l}\text { sakit perut, gatal-gatal, batuk, sakit } \\
\text { pinggang dan pegal-pegal }\end{array}$ \\
\hline 10. & Rute Mulung & $\begin{array}{l}\text { perumahan dan pasar di wilayah Pondok } \\
\text { Benda Pamulang 2, BSD, Villa Dago, } \\
\text { Pasar Cimanggis, Serpong Muncul dan } \\
\text { Jombang Ciputat }\end{array}$ \\
\hline
\end{tabular}


Tabel 2. Komposisi Pekerja Pemulung di wilayah Pamulang 2

\begin{tabular}{ccc}
\hline $\begin{array}{c}\text { Kelompok umur Pe- } \\
\text { mulung }\end{array}$ & Jumlah (orang) & Persen (\%) \\
\hline Anak-anak (6-14 tahun) & 12 & 9,5 \\
Remaja (15-17 tahun) & 36 & 28,6 \\
Dewasa (18-55 tahun) & 78 & 61,9 \\
Jumlah & 126 & 100 \\
\hline Penghitungan & data & komposisi
\end{tabular}

jumlah pemulung tidak begitu akurat. Hal ini berdasarkan hitungan dari sumber antar teman sejawat pemulung. Ketidakakuratan disebabkan setiap hari jumlah pemulung terkadang bertambah dan berkurang. Jumlah pemulung berdasarkan lokasi lapak yang ada di wilayah Pamulang 2 berjumlah 12 lapak. Setiap lapak terdapat 8-12 pemulung.

Kegiatan pemulung biasanya dimulai pukul 06.00 bahkan ada yang selepas sholat subuh mulai keluar. Aktivitas diawali dengan menyiapkan alat-alat pendukung seperti, gerobak, karung, sepatu bot dan besi pengais sampah. Mereka menyusuri jalan mendatangi tong-tong sampah sambil mengorek dan mengais-ngais mencari barang bekas yang masih memiliki daya jual. Saat memulung banyak dari pemulung yang sering menemukan bahan yang masih bisa dimakan, seperti buah-buahan yang biasanya langsung dimakan tanpa harus dicuci, atau juga menemukan sayuran juga bumbu masak seperti cabe, bawang, lengkuas, jahe dll biasanya mereka bawa pulang untuk bahan masakan di rumah. Sering pula pemulung menemukan uang, handphone, atau menemukan barang bekas yang masih dapat digunakan untuk keperluan keluarga.

Pukul 11.00 biasanya para pemulung berhenti untuk makan dan beristirahat sejenak dimana saja. Pemulung tidak makan dan minum sepuasnya tetapi secukupnya sesuai kemampuan mereka. Makan dan minumnya dapat berupa nasi bungkus beserta lauknya, kadang mie instan atau nasi goreng yang sudah mereka siapkan dari rumah. Setelah istirahat pekerjaan dilanjutkan sampai sore hari. Biasanya sekitar pukul 17.00 atau 18.00 para pemulung kembali ke lapak, membersihkan diri lalu makan malam.
Pada sore hingga malam hari setelah sampai di lapak pemulung biasa melakukan pensortiran hasil pulungan yang seharian dicarinya berdasarkan jenis dan harganya. Untuk hasil pulungan yang masih basah biasanya pemulung akan menjemurnya sampai betul-betul kering hal ini dikarenakan akan terjadi penyusutan harga kisaran $10-30 \%$ jika barang yang ditimbang masih keadaan basah. Setelah dikelompokkan kemudian diikat dan disimpan sampai hari penimbangan datang. Penimbangan biasa dilakukan setiap 10 hari atau setiap seminggu sekali dan langsung dibayar oleh pemilik lapak. Ada juga pemotongan hasil penimbangan oleh pemilik lapak jika pemulung tersebut memiliki hutang. Hutang yang dibayarkan berdasarkan dengan mencicil setiap kali melakukan penimbangan.

Berikut aktivitas keseharian pemulung di wilayah Pamulang 2 yang disajikan dalam bentuk table 3 .

Tabel 3. Aktivitas Keseharian Pemulung

\begin{tabular}{ll}
\hline Kegiatan & Waktu Kerja \\
\hline Pengumpulan barang bekas & Pukul 04.00-12.00 \\
Istirahat makan siang & Pukul 12.00-13.00 \\
Lanjutan kerja pengumpulan barang bekas & Pukul 13.00-18.00 \\
$\begin{array}{l}\text { Pengelompokkan atau sortir dan pengemasan } \\
\text { barang bekas dan penimbangan }\end{array}$ & Pukul 18.00-21.00 \\
$\begin{array}{l}\text { Pengumpulan barang bekas pada malam hari } \\
\text { Istirahat tidur }\end{array}$ & Pukul 21.00-23.00 \\
\hline
\end{tabular}

Jadwal kerja pemulung tidak menentu, namun secara periodik berlangsung secara rutin. Kegiatan mulung dalam satu lapak dilakukan secara bergantian, sehingga di antara pemulung terjadwal sesuai kesepakatan dan laju wilayah operasi.

Berdasarkan tabel di atas menunjukkan bahwa jam kerja pemulung sangat panjang dan tidak tentu, jadi pemulung bukanlah golongan masyarakat pengangguran karena dengan ratarata kerja 13-15 jam per hari, dalam satu minggu total waktu jam kerja pemulung yaitu 90 jam. Artinya pemulung dikatakan lebih produktif dan lebih panjang waktu kerjanya dibanding pekerja di lapangan formal yang memiliki total waktu jam kerja antara 41-54 jam dalam seminggu. Berikut penjelasan tentang Lapisan Sosial, karakteristik dan Jumlah Populasi Pemulung di Wilayah pamulang 2. 
Tabel 4. memberikan gambaran bahwa pihak yang bekerjasama pada komunitas pemulung di wilayah Pamulang 2 dapat terjadi pada suatu lapisan sosial dan antar lapisan sosial. Pemulung dengan pemulung dapat melakukan kerjasama dalam bentuk sumbangan dengan materi uang ditemukan paling banyak pada saat meringankan beban temannya yang terkena musibah/sakit. Pemulung dengan Bandar (Bandar kecil maupun besar) lebih banyak dalam bentuk pinjam-meminjam, buruh-majikan, dan jual beli. Biasanya pemulung terikat dengan pihak Bandar tertentu karena pinjaman yang diberikan Bandar. Status pemulung demikian biasanya secara otomatis menjadi buruh/ anak buah Bandar yang bersangkutan, dan mempunyai kewajiban untuk menjual hasil pulungannya kepada Bandar majikannya.

Tabel 4. Lapisan Sosial, karakteristik dan Jumlah Populasi Pemulung di Wilayah pamulang 2

\begin{tabular}{|c|c|c|}
\hline $\begin{array}{l}\text { Lapisan } \\
\text { (Status) } \\
\text { Sosial }\end{array}$ & Karakteristik & $\begin{array}{l}\text { Jumlah (Popu- } \\
\text { lasi/orang) }\end{array}$ \\
\hline \multirow[t]{6}{*}{$\begin{array}{l}\text { Bandar } \\
\text { Besar }\end{array}$} & $\begin{array}{l}\text { Memiliki anak buah pemulung } \\
\text { lebih dari } 12 \text { orang }\end{array}$ & \multirow[t]{6}{*}{2} \\
\hline & $\begin{array}{l}\text { Memiliki lapak penampungan } \\
\text { barang yang luas }\end{array}$ & \\
\hline & $\begin{array}{l}\text { Di samping memiliki lapak, istri } \\
\text { atau anak dari bandar juga me- } \\
\text { miliki warung yang menyediakan } \\
\text { kebutuhan sehari-hari pemulung }\end{array}$ & \\
\hline & Sebagai majikan/juragan/bos & \\
\hline & $\begin{array}{l}\text { Biasanya cenderung sebagai pem- } \\
\text { impin pendapat (opinion leader) }\end{array}$ & \\
\hline & $\begin{array}{l}\text { Dalam ekonomi dapat disejajarkan } \\
\text { sebagai lembaga pemasaran/agen }\end{array}$ & \\
\hline \multirow[t]{5}{*}{$\begin{array}{l}\text { Bandar } \\
\text { Kecil }\end{array}$} & $\begin{array}{l}\text { Memiliki anak buah pemulung } \\
5-10 \text { orang }\end{array}$ & \multirow[t]{5}{*}{12} \\
\hline & Memiliki lapak penampungan & \\
\hline & Sebagai majikan/juragan kecil/bos & \\
\hline & $\begin{array}{l}\text { Biasanya cenderung sebagai } \\
\text { penerus komunikasi (lintas } \\
\text { pemulung) }\end{array}$ & \\
\hline & $\begin{array}{l}\text { Dalam ekonomi dapat disejajarkan } \\
\text { dengan peran pedagang pengum- } \\
\text { pul/collector }\end{array}$ & \\
\hline \multirow[t]{2}{*}{ Pemulung } & $\begin{array}{l}\text { Merupakan status sosial yang } \\
\text { paling rendah dan tidak memiliki } \\
\text { modal }\end{array}$ & \multirow[t]{2}{*}{126} \\
\hline & $\begin{array}{l}\text { Bekerja sebagai buruh/anak buah } \\
\text { dan berperan sebagai produsen }\end{array}$ & \\
\hline
\end{tabular}

Dalam suatu masyarakat, norma yang mengatur kerja sama di antara anggotanya dapat berupa imbalan atau sanski. Dengan kata lain, norma yang mengatur kerja sama dalam masyarakat merupakan alasan yang mendorong terjadinya kerja sama. Pada kasus komunitas pemulung di wilayah Pamulang 2, norma yang mengatur kerja sama baik antara pemulung dengan pemulung, pemulung dengan Bandar, maupun Bandar dengan Bandar dilandasi oleh norma imbalan dan sanksi. Dari hasil observasi, pemulung yang berhasil memperoleh hasil pulungan dalam jumlah banyak sehingga dia tidak mampu untuk membawa barangnya ke tempat lapak majikannya, dia dapat meminta bantuan temannya untuk mengangkutnya dengan sejumlah imbalan yang sudah disepakati. Sumber persaingan, di antara anggota lapisan sosial pemulung pada umumnya bersumber dari persaingan untuk mendapatkan dan atau menguasai barang-barang hasil pulungan yang memiliki nilai ekonomi (plastik, kardus, botol dari bahan gelas, dan logam), wilayah operasi, dan penguasaan tenaga kerja pemulung. $\mathrm{Hal}$ tersebut digambarkan pada Tabel berikut.

Tabel 5. Sumber Persaingan Antar Lapisan Sosial para Pemulung di Wilayah Pamulang 2

\begin{tabular}{|c|c|c|c|}
\hline Pelaku & Pemulung & Bandar Kecil & Bandar Besar \\
\hline Pemulung & $\begin{array}{l}\text { Wilayah } \\
\text { operasi }\end{array}$ & $\begin{array}{l}\text { Barang hasil } \\
\text { pulungan dan } \\
\text { penguasaan } \\
\text { tenaga kerja }\end{array}$ & $\begin{array}{l}\text { Barang hasil } \\
\text { pulungan dan } \\
\text { penguasaan tenaga } \\
\text { kerja }\end{array}$ \\
\hline $\begin{array}{l}\text { Bandar } \\
\text { kecil }\end{array}$ & & $\begin{array}{l}\text { Barang hasil } \\
\text { pulungan dan } \\
\text { penguasaan } \\
\text { tenaga kerja }\end{array}$ & $\begin{array}{l}\text { Barang hasil } \\
\text { pulungan dan } \\
\text { penguasaan tenaga } \\
\text { kerja }\end{array}$ \\
\hline $\begin{array}{l}\text { Bandar } \\
\text { besar }\end{array}$ & & & $\begin{array}{l}\text { Barang hasil } \\
\text { pulungan dan } \\
\text { penguasaan tenaga } \\
\text { kerja }\end{array}$ \\
\hline
\end{tabular}

Sumber : Hasil Survei Lapangan, 2012.

Sumber persaingan antara pemulung dengan pemulung biasanya berkaitan dengan wilayah operasi mulung yang lokasinya mudah terjangkau dengan jarak yang relatif dekat dengan tempat tinggal pemulung. Faktor kecekatan tangan, keterampilan dan daya tahan fisik akan menentukan seberapa banyak mereka akan memperoleh/mengumpulkan barangbarang sampah yang masih memiliki nilai ekonomi.

Dari pengamatan dan sosialisasi observer pada masyarakat pemulung di wilayah Pamulang 2 diperoleh kesan yang aman, damai dan dinamis. Derajat konflik rendah, hal ini konsisten dengan situasi persaingan yang wajar. 
Kondisi ini agaknya dipengaruhi dari faktor homogenitas etnis pemulung dan Bandar yang umumnya berasal dari daerah yang sama, dan atau kepentingan pemulung, dan Bandar dari segi ekonomi dan sosial sementara sudah relatif terpenuhi.

Lingkungan eko-sosial kehidupan pemulung merupakan suatu kondisi khusus yang membutuhkan penyesuaian diri (copping and adjustment) yang spesifik. Penyesuaian diri ini merupakan salah satu aspek penting dalam kestabilan kesehatan mental mereka. Kesehatan mental itu sendiri dapat diartikan sebagai kemampuan pemulung menyesuaikan diri dengan sumber-sumber stres, baik dari diri sendiri maupun dari lingkungan eko-sosialnya. Oleh sebab itu pemahaman diri menjadi salah satu faktor penentu. Jika seorang pemulung memahami diri secara negatif, maka sumber stres internal semakin tinggi dan kemungkinan besar akan mengalami stres yang berat atau gangguan kesehatan mental. Selanjutnya, jika pemulung itu tidak mendapatkan dukungan sosial yang positif, Ia kemungkinan akan menarik diri dari relasi sosial dan mengalami aliensi sosial yang merupakan salah satu sumber gangguan kesehatan mental.

Di wilayah Pamulang 2 sebagian besar pemulung merasa masalah sebagai hal yang harus diatasi. Bahkan dengan adanya masalah, sebagian besar pemulung menjadi lebih giat dalam bekerja. Sedangkan upaya mengatasi masalah dengan pendekatan emosional juga cukup banyak dilakukan oleh para pemulung. Dari gambaran tersebut, kedua strategi copping digunakan oleh pemulung untuk mengurangi stres, namun lebih banyak pemulung yang menggunakan strategi problem focused (70 $\%$ daripada strategi emotional focused (60 $\%$. Berdasarkan kondisi ini pemulung di wilayah Pamulang 2 secara psikologis mampu menyelesaikan masalah secara adaptif pada saat mengalami stress. Hal ini merupakan faktor positif mendukung program pemberdayaan.

Resiko terganggunya kesehatan Pemulung, istri dan anak pemulung sangat tinggi. Pada umumnya mereka seringkali dihinggapi penyakit perut, sakit kepala, sesak napas dan infeksi saluran pernapasan akut (ISPA). Penyakit perut dan sakit kepala sudah dirasakan sebagai penyakit menahun. Sakit perut yang diderita diduga disebabkan cemaran bakteri sampah pada makanan dan air minum yang diduga disebabkan oleh timbunan sampah yang berada di lingkungan mereka.

Beberapa faktor yang menyebabkan pemulung, istri, dan anaknya pemulung seringkali mengalami gangguan kesehatan, selain tidak mencoba untuk melakukan pencegahan, pengetahuan tentang kesehatan yang rendah. Faktor lainnya yang turut memperparah kondisi kesehatan pemulung, yaitu:

a. Tidak memakai pelindung tubuh yang memadai saat bekerja,

b. Penyebaran bibit penyakit dari tempat penimbunan limbah sampah/barang bekas yang sangat dekat dengan lokasi rumah,

c. Kurangnya pengetahuan kesehatan.

Kegiatan pemulung mencakup pencarian barang bekas di berbagai wilayah yang disusuri, pensortiran, pengelompokan barang bekas berdasarkan jenisnya, pengepakan dan penimbangan dengan bentuk penjualan kepada Bos (Bandar) pemilik lapak di mana pemulung tersebut tinggal dengan fasilitas yang seadanya. Jumlah barang bekas hasil pencarian pemulung disebut sebagai produk atau hasil mulung. Harga perkilogram masing-masing produk cukup bervariasi. Pemulung menerima sejumlah uang sebagai pendapatan mereka dari penjualan barang bekas yang mereka kumpulkan. Di bawah ini tabel yang menyajikan data jenisjenis dan volume produk yang dikumpulkan, harga masing-masing produk, biaya operasional penerimaan dan pendapatan rata-rata per pemulung, per hari, per sepuluh hari dan per bulan. Lihat Tabel 6.

Pemulung mendapat sejumlah uang dari hasil barang bekas yang layak dijual yang mereka kumpulkan, kemudian dikelompokkan berdasarkan jenisnya, kemudian ditimbang. Berikut disajikan data jenis dan volume produk yang dikumpulkan, harga masing-masing produk, dan rata-rata per pemulung per sepuluh hari. Proses penimbangan biasanya dilakukan per sepuluh hari. 
Tabel 6. Volume Produk dan Pendapatan Pemulung

\begin{tabular}{llll}
\hline Uraian & $\begin{array}{l}\text { Jumlah } \\
\text { (unit, kg) }\end{array}$ & $\begin{array}{l}\text { Harga/ } \\
\text { Satuan }\end{array}$ & Nilai (Rp) \\
A. Produksi & & & \\
\hline $\begin{array}{l}\text { 1. Plastik (botol } \\
\text { minuman mineral) }\end{array}$ & 46 & 300 & 9.660 \\
$\begin{array}{l}\text { 2. Mencos/kertas } \\
\text { (kardus bekas susu) }\end{array}$ & 8 & 300 & 1.680 \\
3. Emberan & 3 & 1500 & 3.150 \\
$\begin{array}{l}\text { 4. Plastik Atom } \\
\text { 5. Besi }\end{array}$ & 2 & 1500 & 1.820 \\
6. Karton & 4 & 400 & 1.440 \\
7. Kaca/Beling & 7 & 250 & 700 \\
8. Kaleng & 4 & 200 & 1.120 \\
Hasil & 78 & 250 & 700 \\
$\begin{array}{l}\text { B. Pengeluaran (ma- } \\
\text { kan, rokok, dll) }\end{array}$ & & & 20.270 \\
C. Pendapatan & & & 6.500 \\
perhari* & & & \\
$\begin{array}{l}\text { D. Pendapatan } \\
\text { perbulan* }\end{array}$ & & & \\
\hline
\end{tabular}

*) pendapatan tentatif

Tabel 7. Jenis dan volume produk yang dikumpulkan, harga masing-masing produk, dan rata-rata per pemulung per sepuluh hari

\begin{tabular}{|c|c|c|c|}
\hline Produk Hasil Mulung & $\begin{array}{l}\text { Jumlah } \\
\text { (per kg) }\end{array}$ & Harga/per kg & Nilai (Rp) \\
\hline $\begin{array}{l}\text { Plastik, karpet, ban } \\
\text { dalam mobil atau } \\
\text { motor }\end{array}$ & 4 & 800 & $3.200,-$ \\
\hline Kantong bening & 10 & 1000 & 10.000,- \\
\hline Kantong kresek & 5 & 500 & $2.500,-$ \\
\hline $\begin{array}{l}\text { Emberan, plastik } \\
\text { minuman air mineral }\end{array}$ & 47 & 2300 & 10.810,- \\
\hline Besi & 2 & 4000 & $8.000,-$ \\
\hline Kertas putih & 25 & 1500 & $37.500,-$ \\
\hline Koran & 20 & 1000 & $20.000,-$ \\
\hline Kardus & 35 & 1200 & $42.000,-$ \\
\hline $\begin{array}{l}\text { Dupleks (bekas katon } \\
\text { susu) }\end{array}$ & 30 & 500 & 15.000,- \\
\hline Kaca/kaca beling & 22 & 500 & 11.000,- \\
\hline Kaleng & 38 & 2700 & $10.260,-$ \\
\hline Total produksi & 238 & & \\
\hline Penerimaan (Rp) & & & $170.270,-*)$ \\
\hline
\end{tabular}

*) penerimaan tentatif

Data tabel di atas juga menunjukkan jumlah bahan/barang bekas yang dapat dikumpulkan seorang pemulung rata-rata sebanyak $238 \mathrm{~kg} /$ sepuluh hari. Jumlah ini disebut sebagai "produk pemulung" yang menunjukkan sejumlah unit barang yang dapat dihasilkan melalui usaha atau daya kerja pemulung. Jumlah yang dapat dikumpulkan pemulung menunjukkan kekuatan tenaga mereka untuk mampu dan aktif berjalan mencari dan mengumpulkan barang bekas.

Rantai tata niaga barang bekas mulai dari pemulung sampai pabrik cukup panjang. Rantai ini melibatkan sejumlah pelaku dengan beberapa tingkatan. Tingkat paling bawah adalah pemulung kemudian pemilik lapak, Bos menengah di lokasi luar lapak dan Bos besar dalam pabrik. Bos dalam pabrik merupakan bos yang berhubungan dengan pabrik. Sedangkan di luar lapak adalah Bos menengah sebagai penghubung Bos besar dalam pabrik, Bos besar di luar lapak membeli hasil barang yang dikumpulkan pemulung kepada pemilik lapak. Berikut ini disajikan rantai tata niaga barang bekas dan perbedaan harga per kilonya di setiap tingkatan.

\section{Bagan 2. Tahap Kegiatan Tata Niaga Pemulung}

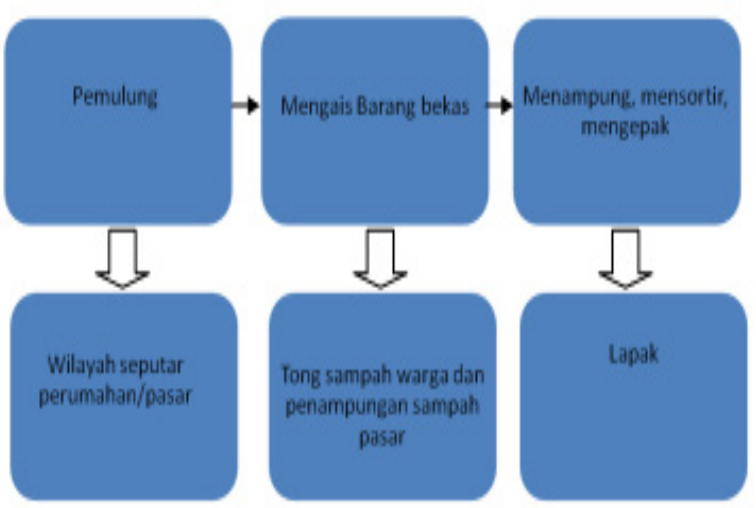

Pemulung diorganisir oleh seorang Bandar atau Bos pemilik lapak. Hasil penelitian lapangan menunjukkan pemulung yang berasal dari desa-desa atau pemulung yang di sekitar lapak direkrut oleh seorang Bos pemilik lapak. Pemulung diajak ikut menjadi anggota lapak dengan sejumlah fasilitas jaminan yaitu makan, tempat tinggal, dan kesehatan termasuk juga mendapat pinjaman uang jika kebutuhannya mendesak. Dalam merekrut pemulung, seorang Bos mengeluarkan sejumlah modal untuk keperluan pemulung. Karena itu hubungan kerja antara Bos pemilik lapak dan pemulung anggotanya terjalin sangat baik.

Pemulung bekerja hanya mencari barang bekas, mengumpulkan dan mengepak kemudian menimbang dan menjual sebagai hasil produk mereka kepada Bos. Pasar pertama yang 
menjadi transaksi barang bekas yaitu antara pemulung dan Bos dan ini terjadi di lokasi lapak. Lokasi di luar lapak, Bos pemilik lapak menjual kepada perantara pabrik yang disebut Bos menengah. Hal itu disebut sebagai pasar tahap kedua transaksi. Pasar tahap ketiga transaksi terjadi antara Bos menengah dengan Bos besar pemilik pabrik. Bagi pemulung ketersediaan transaksi pasar pada lokasi kerja merupakan suatu faktor keuntungan. Karena secara teoritis lokasi pemulung menjual hasil pulungannya dekat dan tidak mengeluarkan biaya sehingga tidak ada biaya transportasi. Keuntungan lain yaitu efisiensi waktu. Pemulung tidak menghabiskan waktu dengan menempuh jarak karena penimbangan dilakukan di lapak tempat dia tinggal.

Berdasarkan kondisi, eksistensi pekerjaan pemulung dapat didefinisikan sebagai suatu pekerjaan sekelompok orang yang bekerja secara individu untuk mengumpulkan barang-barang bekas yang telah dibuang sebagai sampah. Bahan atau barang bekas yang dikumpulkan untuk didaur ulang menjadi barang-barang produk akhir yang mempunyai nilai jual kembali cukup tinggi contohnya plastik bekas, dilebur oleh pabrik kemudian dicetak menjadi bak/ember plastik yang dapat dijual. Produk hasil olahan dari barang bekas dapat berupa bahan setengah jadi yang dibutuhkan pabrik atau produk yang langsung bisa dinikmati masyarakat.

Hasil penelitian lapangan pada tingkat pasar yang lebih tinggi, barang bekas yang dikumpulkan pemulung juga dapat diekspor ke luar negeri contohnya: alumunium, besi, dan tembaga. Pekerjaan pemulung yang mengumpulkan dan mengkategorisasikan barang-barang bekas yang dapat didaur-ulang adalah pekerjaan yang unik. Pada umumnya sebuah pekerjaan dikatakan sebagai sebuah lapangan yang baik, layak dikerjakan seseorang, pada lingkungan yang relatif bersih dan sehat, memiliki nilai yang privilege bagi pelakunya, dan memberikan returns, serta bernilai ekonomi dan sosial yang baik bagi si pelaku maupun bagi orang lain yang terkait dengan pekerjaan tersebut. Dari kriteria pekerjaaan seperti yang disebutkan di atas, maka aktifitas pemulungan atau bahkan disebut pekerjaan pemulung adalah aktifitas yang ditolak atau tidak lazim diterima di dalam masyarakat dan dapat dikatakan tidak layak untuk dikerjakan oleh seseorang.

Namun hasil identifikasi di lapangan menunjukkan pemulung menghargai pekerjaan yang mereka lakukan sebagai pekerjaan yang baik, layak, memberikan privilege bagi mereka dan bernilai ekonomi baik dinikmati oleh mereka maupun masyarakat luas. Pemulung menganggap mereka masih berharga karena masih dapat bekerja dan menikmati nilai ekonomi sebagai retruns dari pekerjaan mereka. Pekerjaan pemulung masih dikategorikan pekerjaan yang layak oleh para pemulung. Berdasarkan pandangan pemulung ini dan dengan mempertimbangkan nilai ekonomi produk akhir hasil olahan bahan bekas dan berbagai sisi positif dari kehadiran pemulung maka dapat dikatakan bahwa pemulung adalah sebuah pekerjaan yang layak diterima oleh masyarakat.

Berdasarkan kajian kondisi teknologi tingkat pemulung, dapat dijelaskan sebagai berikut.

a. Pemulung berstatus sebagai produsen. Dengan cara tertentu pemulung dapat menghasilkan produk pulungan untuk dijual dalam harga tertentu. Cara untuk menghasilkan produk atau teknologi yang digunakan sangat sederhana atau bersifat tradisional. Proses produk pulungan dengan cara mengumpulkan dan memilahmilah atau mengkategorisasikan bahan/ barang bekas tersebut menurut jenis dan selanjutnya sedikit menjemur supaya berkurang kadar air.

b. Pengumpulan dan pemilahan barang dilakukan secara manual, yaitu memilah satu per satu bahan dengan tangan dan mengelompokkan, kemudian dikemas dalam karung yang besar.

c. Biasanya hasil mulung dijemur di tempat lapang, jika sudah kering dan pengumpulan mencukupi siap untuk dijual. Pendapatan dapat diukur sendiri dari stok barang yang terkumpul (masa pengumpulan paling lama 4 hingga 9 hari) sebelum di jual ke lapak.

Dalam proses pengumpulan barang bekas, pemulung melakukan secara manual yaitu memilih satu per satu bahan dari tumpukan hasil mulung dengan menggunakan alat sederhana 
yaitu gancu atau capitan. Hasil memulung biasanya di tempatkan di halaman atau tanah luas dan pemulung melakukan pemisahan barang-barang bekas sesuai dengan kategorinya. Dalam proses mengkategorisasikan barang bekas tersebut, para pemulung menggunakan pengetahuan lokal dan pengalaman yang didapat dari melihat secara langsung fisik bentuk barang. Biasanya mereka juga melakukan kegiatan kategorisasi barang bekas disesuaikan dengan nilai ekonomis, artinya barang bekas yang memiliki nilai ekonomis tinggi dipisahkan dari barang bekas lain yang akan dijual sesuai pemesanan.

Selanjutnya pada proses pemilihan, pemulung juga menggunakan cara manual yaitu memisahkan satu per satu barang bekas dengan tangan dan menggunakan gancu dengan cepat, berikutnya mengelompokkan dan mengemaskan dalam karung-karung besar. Pada saat di lapangan, produk memulung yang paling banyak berupa plastik minuman air mineral dan kertas. Dalam keadaan tertentu, biasanya pemulung melakukan proses penjemuran dan dilakukan juga secara manual, yaitu menguraikan barang bekas di panas matahari supaya produk hasil memulungnya kering dan bersih dari kotoran. Setelah bahan/barang kering, produk hasil memulung dikemas dan siap untuk ditimbang/ dijual di Bandar/lapak/Bos.

Pada tabel 8 dijabarkan gambaran tentang pengetahuan pemulung dalam melakukan kategorisasi barang bekas.

Dengan memperhatikan nilai ekonomis dari barang bekas dan kebermanfaatannya sebagai media pada tingkat realistik, maka dalam proses penanaman konsep pada barang bekas memiliki sejarah dan dimensi pengetahuan yang dapat dijadikan model media pembelajaran yang unik. Barang bekas selain dapat memberikan nilai ekonomis bagi para pemulung juga menjadi media edukasi dan media pengetahuan proses daur ulang bagi siswa dan guru. Dalam penelitian ini perlu dikembangkan beberapa dimensi barang bekas yang dikumpulkan oleh para pemulung dalam bentuk klasifikasi barang bekas, dan dalam hal ini siswa serta guru dapat melakukan kegiatan kategorisasi secara bersama-sama dengan para pemulung. Hasil yang didapat berupa catatan kategorisasi barang bekas secara komprehensif. Selain bermanfaat untuk para pemulung juga dapat dimanfaatkan oleh sekolah sebagai media pembelajaran. Dengan kondisi ini diharapkan dapat terwujud suatu sinergi kemitraan antara para pemulung dengan pihak sekolah.

Tabel 8. Pengetahuan Pemulung tentang Kategorisasi Barang Bekas

\begin{tabular}{|c|c|c|}
\hline No. & $\begin{array}{l}\text { Kategorisasi } \\
\text { Barang Bekas }\end{array}$ & Pengetahuan pemulung \\
\hline 1. & $\begin{array}{l}\text { Kardus/karton / } \\
\text { mencos }\end{array}$ & $\begin{array}{l}\text { Digunakan untuk tempat menyimpan } \\
\text { barang dan mainan bergambar (way- } \\
\text { ang, boneka dll) }\end{array}$ \\
\hline 2. & $\begin{array}{l}\text { Koran/majalah/ } \\
\text { buku-buku }\end{array}$ & $\begin{array}{l}\text { Majalah dan buku dapat dibaca, sedan- } \\
\text { gkan koran untuk bungkus barang dan } \\
\text { bubur koran untuk membuat mainan }\end{array}$ \\
\hline 3. & Kertas buku & $\begin{array}{l}\text { Untuk membungkus makanan (bi- } \\
\text { asanya untuk penjual sayur atau ikan } \\
\text { pindang, dll) dan mainan bergambar }\end{array}$ \\
\hline 4. & $\begin{array}{l}\text { Plastik ember, } \\
\text { baskom dll }\end{array}$ & $\begin{array}{l}\text { Ember yang sudah hancur dilebur jadi } \\
\text { barang lain (daur ulang), seperti pot } \\
\text { tanaman, mainan dll. }\end{array}$ \\
\hline 5. & $\begin{array}{l}\text { Plastik bekas } \\
\text { botol minuman }\end{array}$ & $\begin{array}{l}\text { Digunakan untuk menyimpan benda- } \\
\text { benda kecil (kancing, peniti, dll) dan } \\
\text { pot tanaman organik. }\end{array}$ \\
\hline 6. & $\begin{array}{l}\text { Plastik atom/ } \\
\text { mika }\end{array}$ & $\begin{array}{l}\text { Digunakan untuk membungkus benda } \\
\text { dan penutup }\end{array}$ \\
\hline 7. & $\begin{array}{l}\text { Botol kecap, } \\
\text { sirup dll }\end{array}$ & $\begin{array}{l}\text { Untuk botol bensin atau isi ulang } \\
\text { bahan lain dan alat musik }\end{array}$ \\
\hline 8. & Besi & Tambalan pagar besi, dll \\
\hline 9. & $\begin{array}{l}\text { Kaleng minuman } \\
\text { bersoda, biskuit }\end{array}$ & $\begin{array}{l}\text { Buat lempengan, dijadikan pagar dind- } \\
\text { ing dan pot tanaman organic }\end{array}$ \\
\hline 10. & Karpet talang & $\begin{array}{l}\text { Tambalan kursi/meja dan penutup } \\
\text { atap }\end{array}$ \\
\hline 11. & Kaca/Beling & $\begin{array}{l}\text { Dihancurkan menjadi serbuk kaca } \\
\text { (tidak tahu untuk apa?) selain itu untuk } \\
\text { mainan dimensi, aquarium mini, dll. }\end{array}$ \\
\hline 12. & $\begin{array}{l}\text { Ban dalam dan } \\
\text { luar sepeda/ } \\
\text { mobil }\end{array}$ & $\begin{array}{l}\text { Ban dalam untuk tali ikat, ban luar un- } \\
\text { tuk pembatas, ayunan, pot tanaman, dll }\end{array}$ \\
\hline
\end{tabular}

\section{Penutup}

Sebagian besar pemulung hanya memperoleh pendidikan dasar, akan tetapi mereka memiliki keinginan besar untuk menyekolahkan anaknya lebih tinggi. Bagi anakanak yang ikut dalam memulung biasanya juga akan berhenti sekolah karena lebih menyukai memulung dan mendapatkan uang. Kondisi ini terus menerus terjadi dari generasi ke generasi. Sebagian dari pemulung memiliki keterampilan sebagai tukang bangunan, penebang pohon, pembersih jalanan/saluran air, perbaikan 
barang/alat, dan lain-lain. Proses penanaman konsep pada barang bekas memiliki sejarah dan dimensi pengetahuan yang dapat dijadikan model media pembelajaran yang unik. Melalui barang bekas selain dapat memberikan nilai ekonomis bagi para pemulung juga menjadi media edukasi dan media pengetahuan proses daur ulang bagi siswa dan guru.

Penelitian kualitatif mendalam perlu ditindaklanjuti dan dikembangkan dengan melibatkan unsur stakeholder dan pemda terkait. Hasil temuan di lapangan menjadi kajian untuk pengambilan kebijakan dalam pemberdayaan pemulung untuk pengelolaan lingkungan yang terintegratif dan edukatif. Beberapa dimensi barang bekas yang dikumpulkan oleh para pemulung dalam bentuk kategorisasi barang bekas dapat dilakukan sebagai proses pembelajaran siswa dan guru di sekolah. Hasil yang didapat berupa catatan kategorisasi barang bekas secara komprehensif menjadi model pemberdayaan antara pemulung dengan masyarakat. Selain bermanfaat untuk para pemulung juga dapat dimanfaatkan oleh masyarakat sekolah sebagai media pembelajaran. Dengan kondisi ini diharapkan dapat terwujud suatu sinergi kemitraan antara para pemulung, masyarakat dan pihak sekolah.

\section{E. Daftar Pustaka}

Fedyani, S. (2011). Catatan Refleksi Antropologi Sosial Budaya. Jakarta: Institut Antropologi Indonesia (IAI).

Gerungan. (2009). Psikologi Sosial. Jakarta: Pratama.

Hartono, D. (2005). Alternatif Pemenuban Kebutuhan Air Bersib oleh PDAM Kota Semarang. Tesis Program Pascasajana, Magister Teknik Pembangunan Wilayah dan Kota, Universitas Diponegoro. (tidak dipublikasikan).

Purba, J. (2002). Pengelolaan Lingkungan Sosial. Jakarta: Yayasan Obor Indonesia.

Subagyo, J. (2003). Hukum Lingkungan, Masalah Dan Penanggulangannya. Jakarta: Rineka Cipta.

Sukmana, Oman. (2003). Dasar-Dasar Psikologi Lingkungan. Malang: Bayu Media.

Walgito, B. (1994). Psikologi Sosial. Yogyakarta: Andi Offset.

Young, G. L. (1994). "Passamaquoddy Technology Recovery Scrubber - Process Update"; Specialty Conference on Waste Combustion in Boilers and Industrial Furnaces, Air \& Waste Management Association, Kansas City. 